\title{
NRG2 Gene
}

National Cancer Institute

\section{Source}

National Cancer Institute. NRG2 Gene. NCI Thesaurus. Code C24641.

This gene is involved in cellular differentiation, growth and proliferation. 